\title{
Variability and performance evaluation of introgressed Nigerian dura $x$ Deli dura oil palm progenies
}

\author{
A. Noh', M.Y. Rafii ${ }^{2,3}$, A. Mohd Din ${ }^{1}$, A. Kushairi ${ }^{1}$, A. Norziha ${ }^{1}$, \\ N. Rajanaidu ${ }^{1}$, M.A. Latif ${ }^{2}$ and M.A. Malek $^{3}$ \\ ${ }^{1}$ Malaysian Palm Oil Board, Bandar Baru Bangi, Kajang, \\ Selangor, Malaysia \\ ${ }^{2}$ Department of Crop Science, Faculty of Agriculture, Universiti Putra Malaysia, \\ UPM Serdang, Selangor, Malaysia \\ ${ }^{3}$ Institute of Tropical Agriculture, Universiti Putra Malaysia, UPM Serdang, \\ Selangor, Malaysia
}

Corresponding author: M.Y. Rafii

E-mail: mrafii@upm.edu.my

Genet. Mol. Res. 13 (2): 2426-2437 (2014)

Received December 6, 2012

Accepted June 10, 2013

Published April 3, 2014

DOI http://dx.doi.org/10.4238/2014.April.3.15

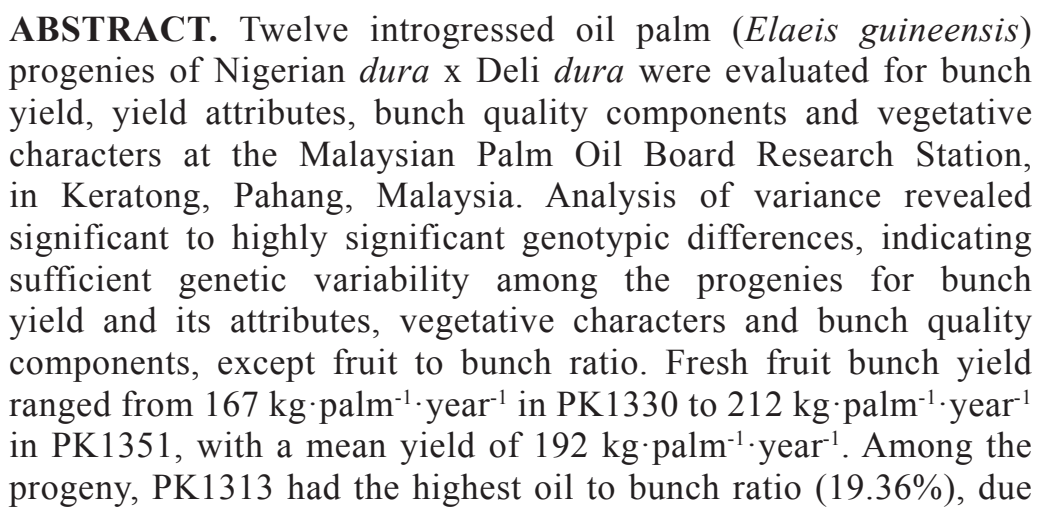


to its high mesocarp to fruit ratio, fruit to bunch ratio and low shell to fruit ratio. Among the progenies, PK1313 produced the highest oil yield of $31.4 \mathrm{~kg} \cdot \mathrm{palm}^{-1} \cdot$ year $^{-1}$, due to a high mesocarp to fruit ratio $(61.2 \%)$ and a low shell to fruit ratio $(30.7 \%)$, coupled with high fruit to bunch ratio (65.6\%). PK1330 was found promising for selection, as it had desirable vegetative characters, including smaller petiole cross section $\left(27.15 \mathrm{~cm}^{2}\right)$, short rachis length $(4.83 \mathrm{~m})$, short palm height $(1.85 \mathrm{~m})$, and the lowest leaf number (164.6), as these vegetative characters are prerequisites for selecting palms for high density planting and high yield per hectare. The genetic variability among the progenies was found to be high, indicating ample scope for further breeding, followed by selection.

Key words: Oil palm; Heritability; Introgressed progenies; Nigerian dura; Deli dura

\section{INTRODUCTION}

Palm oil is one of the world's healthiest oils and a major crop that ranks second in the world market as a producer of vegetable fats and oils. As a natural vegetable oil, it contains no trans fatty acids or cholesterol. It is currently being used by doctors and government agencies to treat specific illnesses and improve nutritional status. Recent medical studies have shown that palm oil, particularly virgin (red) palm oil, can protect against many common health problems (Bruce, 2007). To achieve sustainable agricultural production and food security, current research efforts have been directed to systematic varietal improvement programs to generate a superior population with improved productivity. As the leader of oil palm industry in Malaysia, the Malaysian Palm Oil Board (MPOB) has assembled a large collection of oil palm germplasm from Africa and South/Central America for the development of elite planting materials for growers to achieve sustainable production. These collections were systematically planted and evaluated in a field genebank at MPOB Kluang, Johor in 1975/76. The first collection was from Nigeria in 1973 (Rajanaidu et al., 2008). Due to the narrow genetic base of the existing native oil palm materials, it was essential to introgress genes from new germplasm sources into existing populations, to broaden their genetic base. To achieve this new germplasm, sources were introduced from abroad to enrich the genetic base of the current native breeding materials. The first generation of the Nigerian Material was utilized by MPOB to produce value added planting material and released to the industry in 1994 (Rajanaidu et al., 2008). These materials were also distributed to the industry and have been utilized in their breeding programs to produce new generations of planting materials for the future. In Federal Land Development Authority (FELDA), the materials were extensively used in their dura $\mathrm{x}$ tenera $(\mathrm{D} \times \mathrm{T})$, tenera $\mathrm{x}$ tenera $(\mathrm{T} \times \mathrm{T})$, dura $\mathrm{x}$ dura $(\mathrm{D} \times \mathrm{D})$ and dura $\mathrm{x}$ pisifera $(\mathrm{D} \times$ P) crossing program (Junaidah et al., 2008; 2011). Their Deli dura $\mathrm{x}$ Nigerian dura progenies produced high fresh fruit bunch (FFB) yield $(26.47 \mathrm{t} / \mathrm{ha})$, oil to bunch ratio $(\mathrm{O} / \mathrm{B})$ ranging from 19.4 to $23.8 \%$ and height increment from 0.38 to $0.46 \mathrm{~m} /$ year (Junaidah et al., 2008). The D x D Nigerian population was also reported to produce high FFB yield (180.6 to $231.3 \mathrm{~kg} \cdot \mathrm{palm}$ ${ }^{1}$.year ${ }^{1}$ ) and $\mathrm{O} / \mathrm{B}$ ranging from 15.49 to $19.19 \%$ (Veriappan et al., 2008). 
Nigerian materials were also distributed to the Eastern Plantation Agency (EPA) in 1991 and field planted in 1992. The FFB production of their D x T and T x D progenies planted in Pasak Estate, Kota Tinggi, Johor was the highest with $149 \mathrm{~kg} \cdot \mathrm{palm}^{-1} \cdot \mathrm{year}^{-1}$ compared to the commercial D x P (145.64 kg $\cdot$ palm $^{-1} \cdot$ year $\left.^{-1}\right)$ and standard cross $(140.92$ $\mathrm{kg} \cdot \mathrm{palm}^{-1} \cdot$ year $^{-1}$ ) (Isa et al., 2008). The high FFB yield was due to high bunch number (BN) but low bunch weight (BWT). Their bunch characteristics were generally not attractive as compared to the commercial dura x pisifera (D x P) (Isa et al., 2008). In the United Plantation Berhad (UPB), the Nigerian materials were introgressed with their breeding materials (Musa and Gurmit, 2008). The performance of their UPB dura x Nigerian PS2 dura progenies were good with FFB production ranging from 229 to $270 \mathrm{~kg} \cdot \mathrm{palm}^{-1} \cdot \mathrm{year}^{-1}$. O/B was also satisfactory with all progenies exceeding $18 \%$ (Musa and Gurmit, 2008). MPOB also utilized the MPOB-Nigerian materials in a number of varietal development programs. Genetic variation has been previously estimated for the different oil yield components of this crop (Okwuagwu and Tai, 1995; Rafii et al., 2002; Musa et al., 2004; Okwuagwu, 2008) and also in another industrial oil crop physic nut, Jatropha curcus L. (Shabanimofrad et al., 2011; Rafii et al., 2012a). There is, however, a need to estimate genetic variability for the fresh fruit bunch yield traits, bunch quality components and vegetative characters among the different breeding populations for future utilization. This paper outlines the variability study and performance evaluation of 12 introgressed progenies of Nigerian dura x Deli dura planted in MPOB Keratong, Pahang.

\section{MATERIAL AND METHODS}

Twelve introgressed palm progenies (Table 1) were planted in a field trial in April, 1994 on inland soils (Serdang Series) at MPOB Keratong Research Station, Pahang. Performances of the female and male parental lines of the introgressed progenies are shown in Table S1 (Nigerian $d u r a$ ) and Table S2 (Deli dura), respectively.

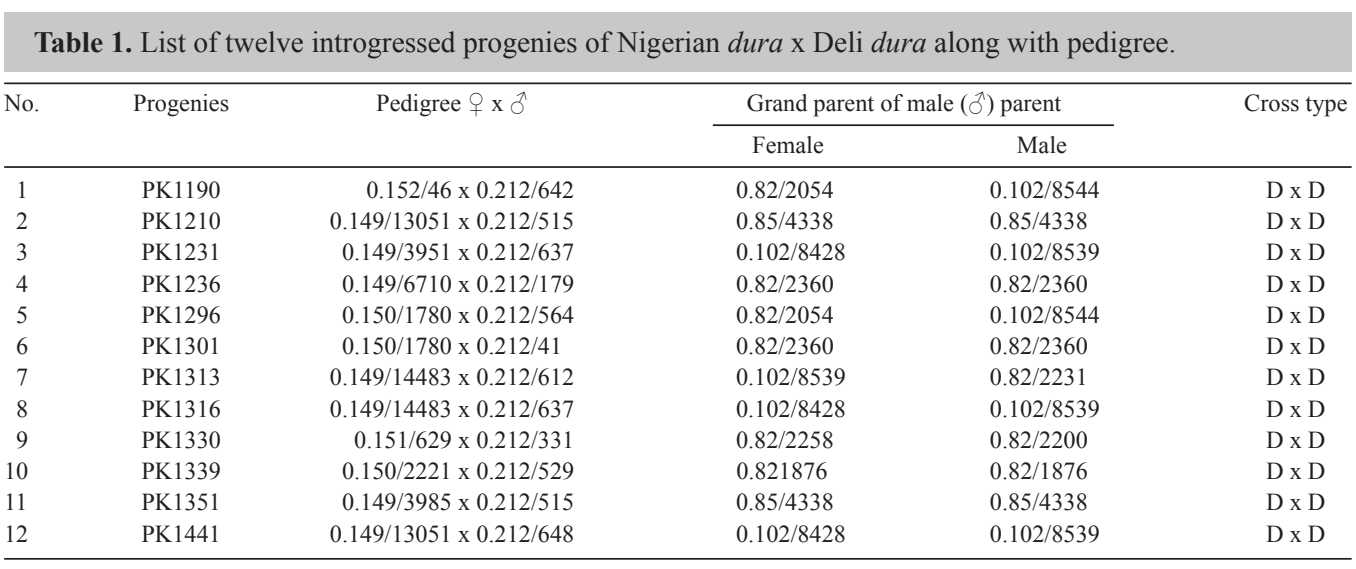

The progenies were laid down in a triangular planting system at $9 \mathrm{~m}$ apart in a randomized complete block design with 16 palm plants per plot in four replications. 
Yield recording of the materials was initiated in 1997 at 37 months after planting at fifteen-day intervals or two rounds per month for a period of seven consecutive years. The fresh fruit bunch FFB yield and its components, namely BN and average bunch weight (ABW) data, were then summarized annually. Analysis of the bunch quality components mesocarp to fruit ratio $(\mathrm{M} / \mathrm{F})$, kernel to fruit ratio $(\mathrm{K} / \mathrm{F})$, shell to fruit ratio $(\mathrm{S} / \mathrm{F})$, oil to dry mesocarp ratio $(\mathrm{O} / \mathrm{DM})$, fruit to bunch ratio $(\mathrm{F} / \mathrm{B})$, oil to bunch ratio $(\mathrm{O} / \mathrm{B})$, kernel to bunch ratio $(\mathrm{K} / \mathrm{B})$, oil yield $(\mathrm{OY})$ and kernel yield $(\mathrm{KY})$ was commenced a year later following the method of Rao et al. (1983) applied by Rafii et al. (2012b). Vegetative measurements including frond production (FP), petiol cross-section (PCS), rachis length (RL), leaflet length (LL), LW leaflet width (LW), leaflet number (LN), palm height (HT), leaflet area (LA), leaf area index (LAI), and trunk diameter (DIAM) were taken at eight years (2002) after field planting, adopting the one-shot method (Breure and Powell, 1987). Palm height was measured from the ground level to the base of frond number 41. Height increment was calculated according to Breure and Powell (1987) using the formula: height increment/year $=($ height at year $\mathrm{t}) /(\mathrm{t}$ 2 ), where $t$ is the age of the palm. All the traits studied were computed for analysis of variance (ANOVA). The data were analyzed by ANOVA and least significant difference (LSD) using the Statistical Analysis System program (SAS Institute, 1992).

Heritability values for each trait were calculated on the basis of the intra-class correlation coefficient $\left(\mathrm{t}_{\mathrm{g}}\right)$ as follows:

$$
t_{g}=\frac{\sigma_{g}^{2}}{\sigma^{2} w+\sigma_{g r}^{2}+\sigma_{g}^{2}}
$$

where:

$$
\begin{aligned}
& \sigma_{\mathrm{g}}^{2}=\text { progeny variance } \\
& \sigma_{\mathrm{gr}}^{2}=\mathrm{G} \times \mathrm{R} \text { variance } \\
& \sigma_{\mathrm{w}}^{2}=\text { within palm variance }
\end{aligned}
$$

According to Falconer and Mackay (1996), in full-sib families, 2t $\mathrm{t}_{\mathrm{g}}$ equals broad sense heritability $\left(h^{2}{ }_{B}\right)$.

\section{RESULTS AND DISCUSSION}

\section{Yield components and yield}

ANOVA for FFB, BN, and ABW revealed the presence of significant genotypic differences, indicating sufficient variability among the introgressed progenies studied for these three traits (Table 2). The results also indicated that there was ample scope for breeding and selection for these traits. Thus, wide variability was exhibited for all three bunch yield traits. Similar findings were reported for yield and related characters by Rafii et al. (2002) and Okoye et al. (2009) in introgressed oil palm. The replicate item was not significant, implying the uniformity of experimental plots. However, the ranking of the progenies for FFB and $\mathrm{BN}$ was not consistent except for $\mathrm{ABW}$ as shown in the replicates $\mathrm{x}$ progenies item in 
ANOVA. FFB recorded the lowest $h^{2}{ }_{B}$ of only $6.47 \%$ as compared to BN and ABW with $h^{2}{ }_{B}$ values of 68.04 and $66.38 \%$, respectively. Low estimate of broad sense heritability in FFB yield indicates a significant role of environment in the expression of this trait. High broad sense heritability was reported for BN and ABW by Musa et al. (2004) and Okwuagwu et al. (2008) from their study on D x P and Deli/dura x tenera breeding populations, respectively, which supports the present result.

\begin{tabular}{|c|c|c|c|c|}
\hline Source & d.f. & FFB $\left(\mathrm{kg} \cdot\right.$ palm $^{-1} \cdot$ year $\left.^{-1}\right)$ & BN (bunches $\cdot$ palm $^{-1} \cdot$ year $^{-1}$ ) & ABW (kg/bunch) \\
\hline Replications (R) & 3 & $3465.67^{\mathrm{ns}}$ & $10.09^{\text {ns }}$ & $15.50^{\mathrm{ns}}$ \\
\hline Progenies $(\mathrm{G})$ & 11 & $7550.49 *$ & $94.70 * *$ & $392.86 * *$ \\
\hline Gx R & 33 & $3557.00 * *$ & $8.68 * *$ & $21.90^{\mathrm{ns}}$ \\
\hline Within palms & 461 & 1951.79 & 4.29 & 18.9 \\
\hline Progeny variance $\left(\sigma^{2}\right)$ & & $70(3.23 \%)$ & $2.48(34.08 \%)$ & $10.04(33.19 \%)$ \\
\hline G x R variance $\left.\left(\sigma^{2}\right)^{g}\right)^{\prime \prime}$ & & $71(3.28 \%)$ & $0.44(5.98 \%)$ & $0.89(2.95 \%)$ \\
\hline Within palms variance $\left(\sigma^{2}\right)$ & & $2022(93.48 \%)$ & $4.37(59.94 \%)$ & $19.32(63.86 \%)$ \\
\hline Broad sense heritability $\left(h^{2}, \%\right)$ & & 6.47 & 68.04 & 66.38 \\
\hline
\end{tabular}

*, **, and ${ }^{\mathrm{ns}}$ indicate significant at $\mathrm{P} \leq 0.05, \mathrm{P} \leq 0.01$ and not significant, respectively; Values in brackets are percentages of the corresponding values of the phenotypic variances; $\mathrm{FFB}=$ fresh fruit bunch; $\mathrm{BN}=$ bunch number; $\mathrm{ABW}=$ average bunch weight.

The performances of the progenies regarding yield and its components are shown in Table 3. Among the progenies, PK1351 (0.149/3985 x 0.212/515) produced the highest FFB yield of $212 \mathrm{~kg} \cdot$ palm $^{-1} \cdot$ year $^{-1}$ which was due to its high ABW $(22.4 \mathrm{~kg} / \mathrm{bunch})$ and moderate BN (9.7 bunches palm ${ }^{-1}$ year $\left.^{-1}\right)$. This result is in contrast to MPOB Nigerian material, characterized by high BN and low ABW (Isa et al., 2008). On the other hand, PK1330 had the lowest FFB yield among the progenies due to its low BN (5.94 bunches palm ${ }^{-1}$ year ${ }^{-1}$ ) but recorded the highest ABW (28.1 kg bunch ${ }^{-1}$ ), which implies that average ABW and moderate BN were prerequisites for high FFB yield.

Table 3. Mean performance of the progenies for FFB yield and its components.

\begin{tabular}{|c|c|c|c|c|c|}
\hline No & Progeny & Pedigree & FFB $\left(\mathrm{kg} \cdot\right.$ palm $^{-1} \cdot$ year $\left.^{-1}\right)$ & BN (bunches $\cdot$ palm $^{-1} \cdot$ year $^{-1}$ ) & $\mathrm{ABW}$ (kg/bunch) \\
\hline 1 & PK1190 & $0.152 / 46 \times 0.212 / 642$ & 199 & 11.0 & 18.0 \\
\hline 2 & PK1210 & $0.149 / 3985 \times 0.212 / 515$ & 186 & 7.7 & 24.2 \\
\hline 3 & PK1231 & $0.149 / 3951 \times 0.212 / 637$ & 185 & 7.5 & 25.0 \\
\hline 4 & PK1236 & $0.149 / 6710 \times 0.212 / 179$ & 185 & 7.4 & 25.5 \\
\hline 5 & PK1296 & $0.150 / 1780 \times 0.212 / 564$ & 179 & 7.0 & 25.8 \\
\hline 6 & PK1301 & $0.150 / 1780 \times 0.212 / 41$ & 196 & 7.2 & 27.7 \\
\hline 7 & PK1313 & $0.149 / 14483 \times 0.212 / 612$ & 198 & 10.8 & 18.7 \\
\hline 8 & PK1316 & $0.149 / 14483 \times 0.212 / 637$ & 207 & 10.4 & 20.0 \\
\hline 9 & PK1330 & $0.151 / 629 \times 0.212 / 331$ & 167 & 5.9 & 28.1 \\
\hline 10 & PK1339 & $0.150 / 2221 \times 0.212 / 529$ & 195 & 9.3 & 21.2 \\
\hline 11 & PK1351 & $0.149 / 3985 \times 0.212 / 515$ & 212 & 9.7 & 22.4 \\
\hline 12 & PK1441 & $0.149 / 13051 \times 0.212 / 648$ & 198 & 8.7 & 23.4 \\
\hline Standard deviation & & & 46.4 & 2.65 & 5.35 \\
\hline $\operatorname{LSD}(\mathrm{P} \leq 0.05)$ & & & 20.2 & 0.95 & 1.95 \\
\hline CV $(\%)$ & & & 24.1 & 30.7 & 23.1 \\
\hline
\end{tabular}

$\overline{\mathrm{FFB}}=$ fresh fruit bunch; $\mathrm{BN}$ = bunch number; $\mathrm{ABW}$ = average bunch weight; LSD = least significant difference; $\mathrm{CV}=$ coefficient variation. 


\section{Bunch quality components}

ANOVA for bunch quality components revealed the presence of significant to highly genotypic differences indicating sufficient genetic variability exists among the progenies for the component characters, i.e., $\mathrm{M} / \mathrm{F}, \mathrm{K} / \mathrm{F}, \mathrm{S} / \mathrm{F}, \mathrm{O} / \mathrm{DM}, \mathrm{O} / \mathrm{B}, \mathrm{K} / \mathrm{B}, \mathrm{KY}$, and $\mathrm{OY}$ but not F/B (Table 4). This was anticipated as the Nigerian material used in this study was from the oil palm germplasm collected from Nigeria in 1973. In oil palm, as in many other crops, a number of generations of selection are required for the material to be genetically stable. Among the traits, $\mathrm{M} / \mathrm{F}$ and $\mathrm{S} / \mathrm{F}$ exhibited moderate heritability values of 55.85 and $49.24 \%$, respectively. The rest of the component traits had low heritability values, which ranged from $6.51 \%$ in OY to $33.04 \%$ in K/F. Low estimate of broad sense heritability indicates a significant role of environment in the expression of these traits. In oil palm breeding, traits with low heritability are normally selected based on the best family and individual selection, while traits with high heritability values may be selected through mass selection.

The performances of the progenies regarding bunch quality components are shown in Table 5. Most of the progenies had moderate mean fruit weight (MFW) with a mean of $10.48 \mathrm{~g}$. $\mathrm{O} / \mathrm{B}$ is an important character in oil palm breeding and selection. It has been reported that Nigerian materials are normally characterized by having small fruit with an MFW of $7.98 \mathrm{~g}$ (Rajanaidu et al., 1999; 2000). The results showed that O/B of the progenies studied was high for dura with all progenies attaining more than $16 \%$. Among the progenies, five (PK1210, PK1301, PK1313, PK1316 and PK1339) were identified with higher O/B, i.e., more than $18 \%$, and among them PK1313 had the highest, $19.4 \%$. The high O/B of PK1313 might have been due to its high M/F (61.15\%) and low S/F (30.72\%) coupled with high F/B (65.56\%). As a result, among the progenies, PK1313 produced the highest oil yield, $31.40 \mathrm{~kg} \cdot \mathrm{palm}^{-1} \cdot$ year $^{-1}$.

\section{Vegetative traits}

All the vegetative traits, i.e., FP, PCS, RL, LL, LW, LN, HT, LA, LAI, and DIAM, showed highly significant differences, indicating the high genetic variability of these traits (Table 6). Heritability estimates for the vegetative traits ranged from $20.69 \%$ in LW to $82.45 \%$ in LL. Among the characters, high estimate of heritability was observed only in RL and LL, with 82.45 and $81.08 \%$, respectively. Characters with lower estimates of broad sense heritability indicate a significant role of environment in the expression of those traits. On the other hand, high broad sense heritability in RL and LL indicates little influence of the environment on the expression of these two traits. Traits with high heritability estimates are generally more amenable for future breeding and selection.

The mean performances of the introgressed progenies regarding vegetative traits are presented in Table 7. The results indicate that the variations observed among the progenies for the vegetative traits were found to be comparable to the progenies of Deli dura x AVROS pisifera (D x P) reported by Noh et al. $(2010 ; 2012)$. Among the progenies, PK1330 was found to have the smallest PCS $\left(27.2 \mathrm{~cm}^{2}\right), \mathrm{RL}(4.8 \mathrm{~m})$ and HT $(1.85 \mathrm{~m})$ and the lowest LN (165 leaflets/frond) as compared to other progenies under trial. Short LL, HT, and small PCS are the prerequisite characters in selecting palms for compactness. Compact palms can be utilized for high density planting and are capable of producing higher yield per hectare. 
A. Noh et al.

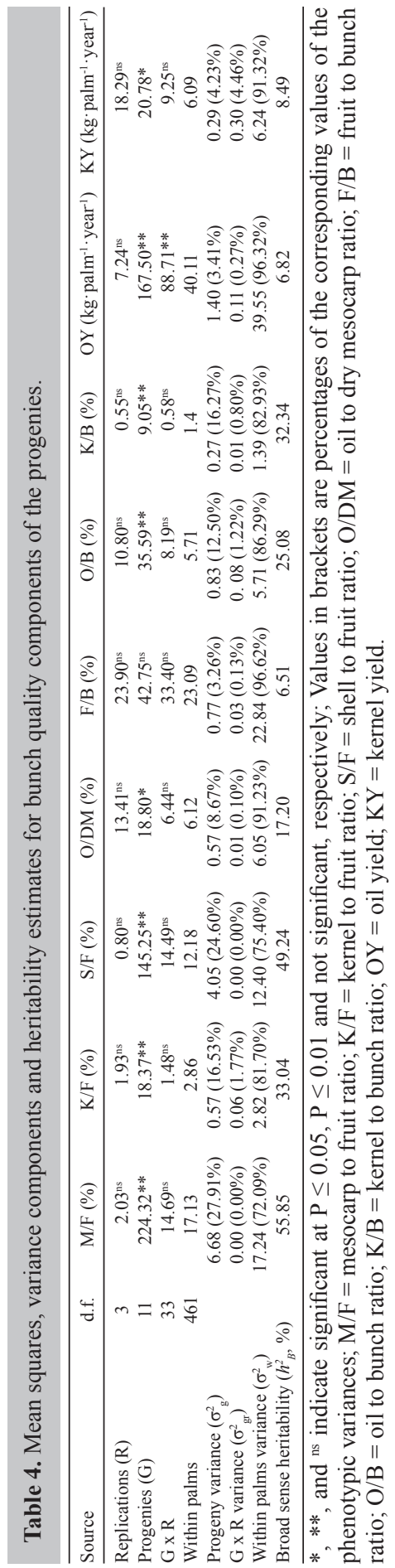




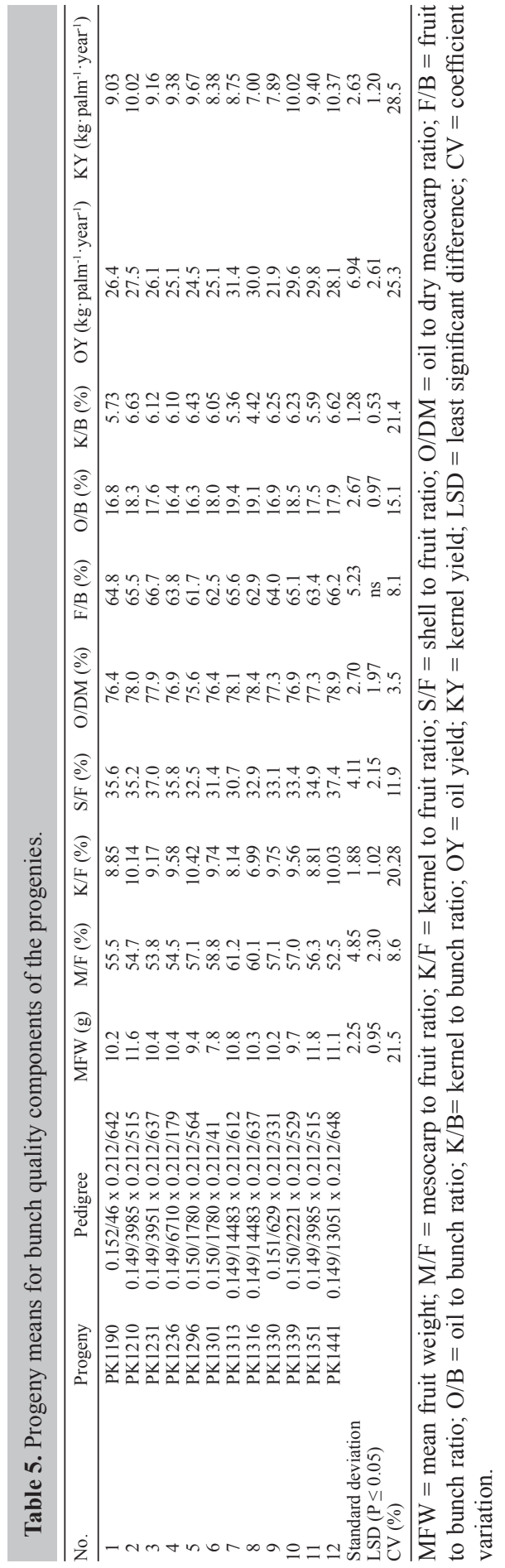


A. Noh et al.

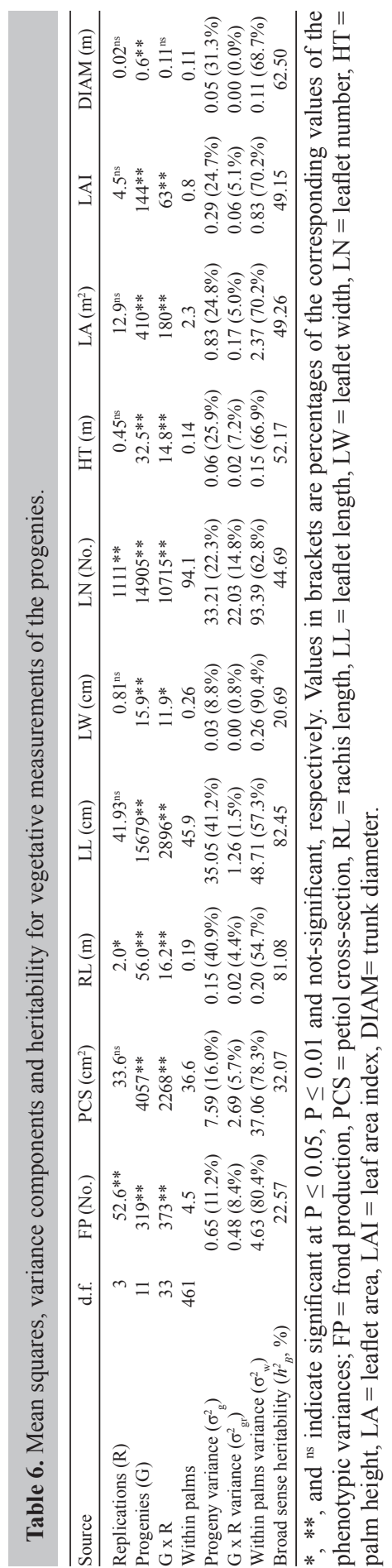




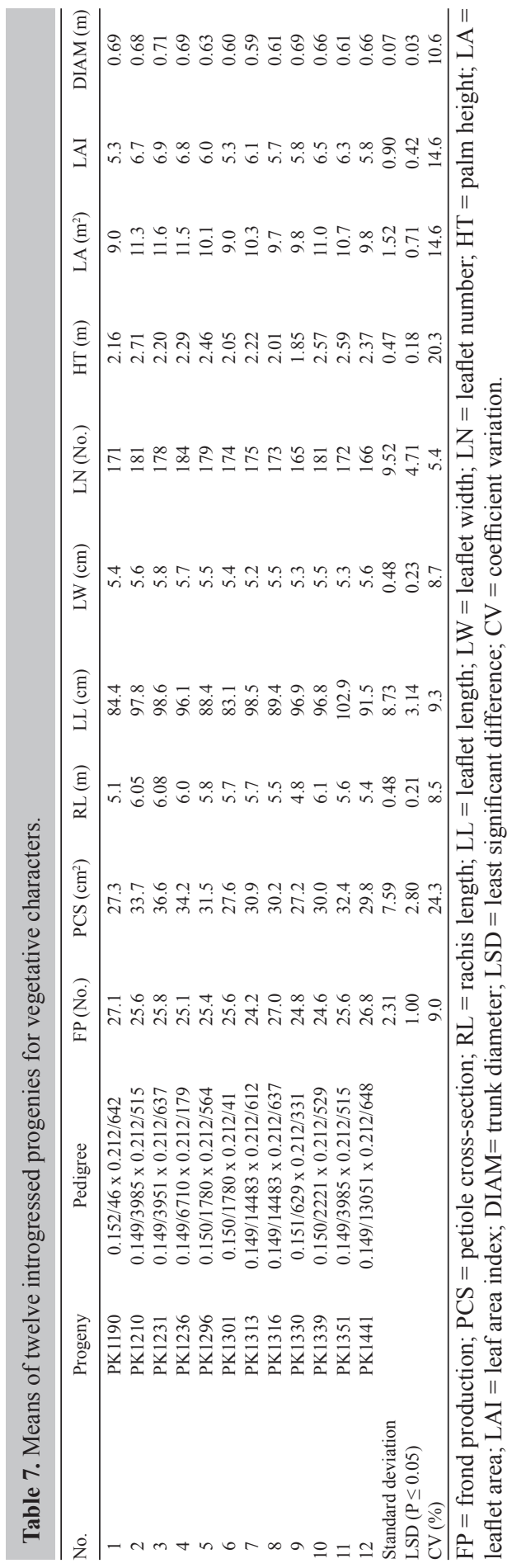




\section{CONCLUSION}

These crossing programs were aimed to broaden dura population genetic base. The genetic variability of the crosses was high for most of the characters, giving ample scope for further selection. A total of 87 palm progenies were selected from this trial based on SIRIM oil palm seed quality production specifications, MS157:2005 (SIRIM, 2005) as dura mother palms for $\mathrm{D} x \mathrm{P}$ seeds production. In addition, the outstanding dura palm progenies from these programs could be cloned and utilized for the production of commercial semi-clonal or clonal $\mathrm{D} \times \mathrm{P}$ planting materials.

\section{ACKNOWLEDGMENT}

The authors greatly acknowledge the Malaysian Palm Oil Board (MPOB) for providing research facilities and financial support for this project.

\section{Supplementary material}

\section{REFERENCES}

Breure CJ and Powell MS (1987). The One-Shot Method of Establishing Growth Parameters in Oil Palm. Proceedings of the International Oil Palm Conference. Palm Oil Research Institute of Malaysia, Kuala, 203-209.

Bruce FND (2007). The Palm Oil Miracle. Colorado Springs, Colo.

Falconer DS and Mackay TFC (1996). Introduction to Quantitative Genetics. 4th edn. Essex, PEL.

Isa ZA, Ong KP, Norasyikin I and Suboh O (2008). Performance of MPOB-Nigerian Population 12 at Kulim - An Update. Proceedings of the 3rd Seminar on Performance of PS1 and PS2 Materials and Elite Germplasm. Malaysian Palm Oil Board, Selangor, 139-149.

Junaidah J, Chin CW, Rafii MY and Syuhada WH (2008). Performance and Utilization of MPOB-Nigerian Oil Palm Materials in FELDA. Proceedings of the 3rd Seminar on Performance of PS1 and PS2 Materials and Elite Germplasm. Malaysian Palm Oil Board, Selangor, 73-90.

Junaidah J, Rafii MY, Chin CW and Saleh G (2011). Performance of tenera oil palm population derived from crosses between deli dura and pisifera from different sources on inland soils. J. Oil Palm Res. 23: 1210-1221.

Musa B and Gurmit S (2008). Utilization of MPOB Germplasm at United Plantations. Proceedings of the 3rd Seminar on Performance of PS1 and PS2 Materials and Elite Germplasm. Malaysian Palm Oil Board, Selangor, 43-60.

Musa BB, Saleh GB and Loong SG (2004). Genetic variability and broad-sense heritability in two Deli-AVROS D x P breeding populations of the oil palm (Elaeis guineensis Jacq.). SABRAO J. Breed. Genet. 36: 13-22.

Noh A, Rafii MY, Saleh G and Kushairi A (2010). Genetic performance of 40 Deli dura x AVROS pisifera full-sib families. J. Oil Palm Res. 22: 781-795.

Noh A, Rafii MY, Saleh G, Kushairi A, et al. (2012). Genetic performance and general combining ability of oil palm Deli dura $\mathrm{x}$ AVROS pisifera tested on inland soils. Scientific World J. 2012: 792601.

Okoye MN, Okwuagwu CO and Uguru MI (2009). Population improvement for fresh fruit bunch yield and yield components in oil palm (Elaeis guineensis Jacq.). Amer. Eurasian J. Sci. Res. 4: 59-63.

Okwuagwu CO and Tai GCC (1995). Estimation of variance components and heritability of bunch yield and yield components in the oil palm (Elaeis guineensis Jacq.). Plant Breed. 114: 463-465.

Okwuagwu CO, Okoye MN, Okolo EC, Ataga CD, et al. (2008). Genetic variability of fresh fruit bunch yield in Deli/dura $\mathrm{x}$ tenera breeding populations of oil palm (Elaeis guineensis Jacq.) in Nigeria. J. Tropical Agric. 46: 52-57.

Rafii MY, Rajanaidu N, Jalani BS and Kushairi A (2002). Performance and heritability estimation on oil palm progenies tested in different environments. J. Oil. Palm Res. 14: 15-24.

Rafii MY, Shabanimofrad M, Puteri Edaroyati MW and Latif MA (2012a). Analysis of the genetic diversity of physic nut, Jatropha curcas L. accessions using RAPD markers. Mol. Biol. Rep. 39: 6505-6511.

Rafii MY, Jalani BS, Rajanaidu N, Kushairi A, et al. (2012b). Stability analysis of oil yield in oil palm (Elaeis guineensis) progenies in different environments. Genet. Mol. Res. 11: 3629-3641. 
Rajanaidu N, Jalani BS, Kushairi A, Rafii MY, et al (1999). Breeding Strategies for the Oil Palm Planting Materials PS1 and PS2 and Furture PS Series. Proceedings of Seminar on PS1 and PS2 Oil Palm Planting Materials. Malaysian Palm Oil Board, Selangor, 76-90.

Rajanaidu N, Kushairi D, Rafii MY, Mohd Din A, et al (2000). Oil Palm Genetic Resources and Their Utilization - a Review. Proceedings of the International Symposium on Oil Palm Genetic Resources and Utilization. Malaysian Palm Oil Board, Kuala Lumpur, 1-55.

Rajanaidu N, Kushairi A, Mohd Din A, Maizura I, et al (2008). A Review on Utilization and Performance of MPOB PS Series Genetic Materials. Proceedings of the 3rd Seminar on Performance of PS1 and PS2 Materials and Elite Germplasm. Malaysian Palm Oil Board, Selangor, 3-25.

Rao V, Soh AC, Corley RHV, Lee CH, et al (1983). A Critical Reexamination of the Method of Bunch Quality Analysis in Oil Palm Breeding. PORIM Occasional Paper, Malaysia.

SAS Institute (1992). SAS/STAT Guide for Personal Computers. Version 9. Ed. Statistical Analysis System Inc., Cary.

Shabanimofrad M, Yusop MR, Saad MS, Megat WPE, et al. (2011). Diversity of physic nut (Jatropha curcas) in Malaysia: Application of DIVA-geographic information system and cluster analysis. Aust. J. Crop Sci. 5: 361-368.

SIRIM (2005). MS157:2005 Oil Palm Seeds for Commercial Planting-Specification. Third Revision. SIRIM, Shah Alam.

Veriapan A, Rajanaidu N, Johari O and Ahmad SF (2008). Performance of MPOB Population 12 at SPAD. Proceedings of the 3rd Seminar on Performance of PS1 and PS2 Materials and Elite Germplasm. Malaysian Palm Oil Board, Selangor, 91-114. 